[Note]

\title{
Flow of Heavy Oil Emulsions through Porous Media
}

\author{
Adnan E. OMaR* and Saad El-Din M. Desouky \\ Petroleum Engineering Dept., King Saud University, \\ P. O. Box 800, Riyadh 11421, Saudi Arabia
}

(Received March 7, 1994)

\begin{abstract}
Rheological and core flow test data were used to develop a relationship between friction factor and Reynolds number for describing the flow of water/oil emulsions through sandstone cores. The developed correlations are used for determining the pressure drop across the porous medium, particularly in enhanced oil recovery process by surfactant flooding.

The crude oil and sandstone cores used were obtained from Saudi oil reservoirs. Experiments were conducted to measure the rheological properties of emulsions and carry out flow tests.

The results showed that the rheological behavior was found to be that of a pseudoplastic that obeys the power-law mode. It was confirmed experimentally that the friction factor and Reynolds number obtained from core tests are inversely proportional regardless of emulsion composition or viscosity.
\end{abstract}

\section{Introduction}

Blake $^{1)}$ was the first to introduce two dimensionless groups to describe the flow of Newtonian fluids through granular beds. They were given by

$$
\begin{aligned}
& f=\frac{\Delta P D_{\mathrm{p}} \phi^{3}}{\rho V_{\mathrm{o}}^{2} L(1-\phi)} \\
& R_{\mathrm{en}}=\frac{D_{\mathrm{p}} V_{\mathrm{o}} \rho}{\mu(1-\phi)}
\end{aligned}
$$

Equations (1) and (2) were used in the majority of papers published on Newtonian flow through granular beds.

Previous studies of the flow of non-Newtonian fluids through porous media were conducted by Sadowski ${ }^{2)}$, Sadowski and Bird ${ }^{3)}$, Camy et al.4), Richardson ${ }^{5)}$, Marsden and Raghavan ${ }^{6)}$, and Alvarado and Marsden ${ }^{7)}$. They have studied rheological behavior of different crude oil emulsions and have concluded that, while many of them behave as Newtonian fluids, some show definite non-Newtonian properties. Of the latter, most are pseudoplastic, but some are dilatant, many are thixotropic and a few are rheopectic. The main reasons for this wide variation in emulsion behavior is due to the great disparity in their composition and the conditions under which

* To whom correspondence should be addressed. they exist. The investigators have suggested several correlations relating the emulsion viscosity to dispersed phase concentration or shear rate using the power-law models ${ }^{8}$.

$$
\tau=H \gamma^{n}
$$

Christopher and Middleman ${ }^{9}$ have modified Eq. (2) for power-law fluids as:

$$
R_{\mathrm{epl}}=\frac{D_{\mathrm{p}} V_{\mathrm{o}}^{2-n} \rho}{\mu_{\mathrm{eff}}(1-\phi)}
$$

where the viscosity level parameter $\left(\mu_{\mathrm{eff}}\right)$ is given by

$$
\mu_{\mathrm{eff}}=\frac{H}{12}\left(9+\frac{3}{n}\right)^{n}(150 K \phi)^{(1-n) / 2}
$$

Equations (1) and (3) through (5) were used to calculate the friction factor and Reynolds number from experimental results. The relation between the friction factor and Reynolds number can be written as follows:

$$
f=\frac{A}{R_{\mathrm{epl}}}
$$

where the constant " $A$ " is experimentally determined.

Once the friction factor is determined from Eq. (6), the pressure gradient across the porous medium can be determined from Eq. (1). 


\section{Experimental Work}

Rheological properties of heavy oil emulsions were measured using a Brookfield viscometer at a constant temperature of $25^{\circ} \mathrm{C}$. The shear rates were ranged from 0.371 to $73.1 \mathrm{~s}^{-1}$. The components of the emulsions were heavy crude oil $\left(\mathrm{API}=27^{\circ}\right)$, brine ( salinity $=15 \%$ by weight $\mathrm{NaCl}$ ), hydrochloric acid (concentration $=2 \%$ by weight), and Triton $\mathrm{X}-100$ as an emulsifier (concentration $=0.5 \%$ by weight). The emulsifier was used to produce stable emulsions. It reduces the interfacial energy, thereby enabling easier formation of the greatly extended interface. It also prevents the coalescence of the droplets once they are formed. The hydrochloric acid was added to the crude oil to dissolve the inorganic materials present.

Figure I shows the flow test apparatus used to measure the pressure drop and flow rate during the flow of emulsions through sandstone cores. The ranges of pressure drop and flow rate were 30 to $145 \mathrm{psi}$ and 0.15 to $1.6 \mu \mathrm{m}^{3} / \mathrm{s}$, respectively. The range of shear rate encountered in core test was from 126.93 to $1,353.9 \mathrm{~s}^{-1}$. Although the range of shear rate encountered in core test $\left(127-1,354 \mathrm{~s}^{-1}\right)$ is higher than that of viscosity data $\left(0.371-73.1 \mathrm{~s}^{-1}\right)$, the type of the emulsion (i.e. pseudoplastic fluid) will not significantly change at higher shear rates. This is a property of pseudoplastic fluid ${ }^{8}$. However, the values of $H$ and $n$ may be changed at higher shear rates, by adding new viscosity data. Since the correlation coefficients of the fitted power-law were statistically checked at confidence level of $99 \%$, the acceptance of the values of $H$ and $n$ at higher shear rates will decrease the confidence level to $95 \%$. It is believed that, this limit is experimentally accepted. The properties of the cores used are given in Table 1. Table 2 shows the mineralogical analysis and relative abundance of clay minerals in the cores. The density of the emulsions was measured using a pycnometer.

\section{Results and Discussion}

The results of emulsion density measurements are given in Table 3. The rheological properties of the emulsions are plotted in Fig. 2. This figure

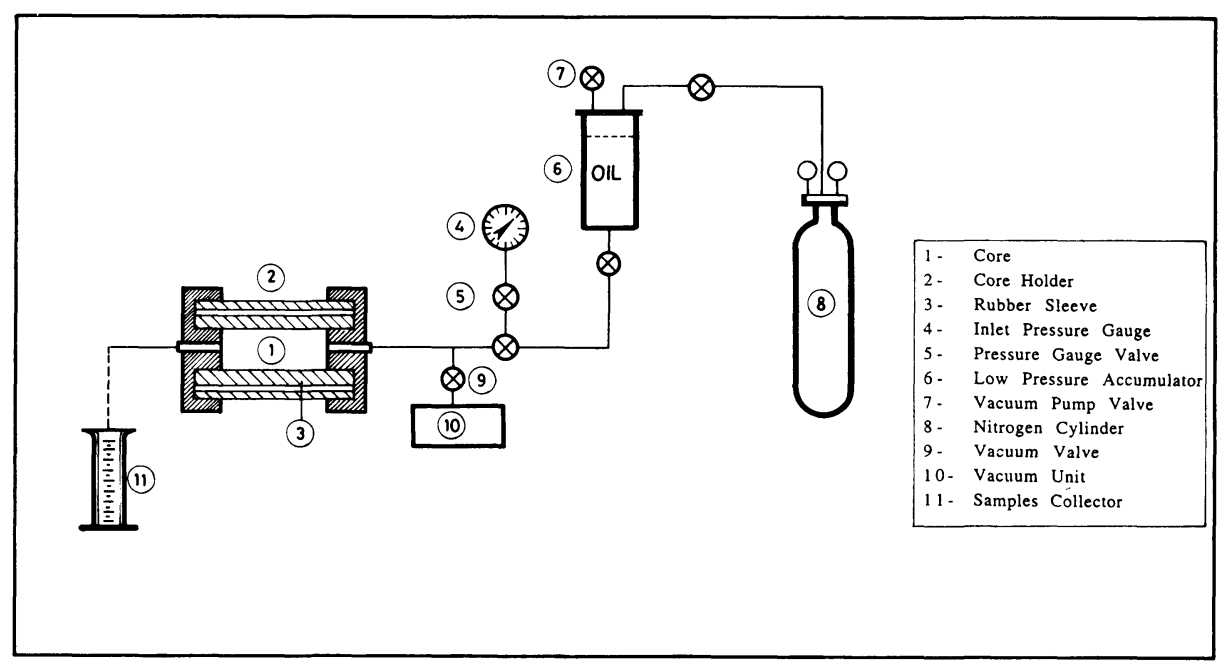

Fig. I Experimental Apparatus

Table 1 Properties of Sandstone Cores

\begin{tabular}{|c|c|c|c|c|c|c|c|}
\hline $\begin{array}{l}\text { Core } \\
\text { No. }\end{array}$ & $\begin{array}{l}\text { Diameter } \\
{[\mathrm{cm}]}\end{array}$ & $\begin{array}{l}\text { Length } \\
{[\mathrm{cm}]}\end{array}$ & $\begin{array}{l}\text { Bulk volume } \\
\qquad\left[\mathrm{cm}^{3}\right]\end{array}$ & $\begin{array}{l}\text { Pore volume } \\
\qquad\left[\mathrm{cm}^{3}\right]\end{array}$ & $\begin{array}{c}\text { Porosity } \\
{[\%]}\end{array}$ & $\begin{array}{l}\text { Initial permeability } \\
{[\mathrm{md}]}\end{array}$ & $\begin{array}{l}\text { Permeability after flow } \\
\text { of } o / w=7 / 3 \text { emulsion }\end{array}$ \\
\hline$\Lambda_{7}$ & 3.60 & 8.65 & 88.05 & 20.12 & 22.85 & 620 & 593 \\
\hline $\mathrm{B}_{2}$ & 3.65 & 6.15 & 64.35 & 13.90 & 21.60 & 593 & 421 \\
\hline $\mathrm{B}_{3}$ & 3.60 & 9.50 & 96.70 & 24.01 & 24.83 & 698 & 651 \\
\hline $\mathrm{C}_{1}$ & 3.60 & 7.50 & 76.34 & 18.27 & 23.93 & 638 & 514 \\
\hline $\mathrm{C}_{2}$ & 3.65 & 9.30 & 97.31 & 23.99 & 24.66 & 656 & 637 \\
\hline $\mathrm{D}_{2}$ & 3.65 & 8.30 & 86.85 & 20.71 & 23.85 & 650 & 569 \\
\hline $\mathrm{E}_{3}$ & 3.60 & 8.30 & 84.48 & 20.29 & 24.01 & 646 & 569 \\
\hline $\mathrm{G}_{1}$ & 3.65 & 8.30 & 86.85 & 19.09 & 21.98 & 609 & 569 \\
\hline $\mathrm{X}_{1}$ & 3.60 & 8.90 & 90.59 & 22.62 & 22.76 & 635 & 610 \\
\hline $\mathrm{X}_{2}$ & 3.60 & 8.90 & 90.59 & 21.49 & 23.73 & 622 & 610 \\
\hline
\end{tabular}


Table 2 Mineralogical Analysis and Relative Abundance of Clay Minerals in the Cores

\begin{tabular}{lcllc}
\hline \multicolumn{2}{l}{ Mineralogical analysis } & & \multicolumn{2}{c}{ Clay minerals } \\
\cline { 1 - 1 } \cline { 4 - 5 } Element & wt $\%$ & & Element & $\begin{array}{c}\text { Relative } \\
\text { abundance }\end{array}$ \\
\hline Quartz & 85 & & Kaolinite & 40 \\
Feldspar & 3 & & Chlorite & 27 \\
Clay & 8 & & Illite & 17 \\
Pyrite & 4 & & Montmorillonite & 6 \\
\hline
\end{tabular}

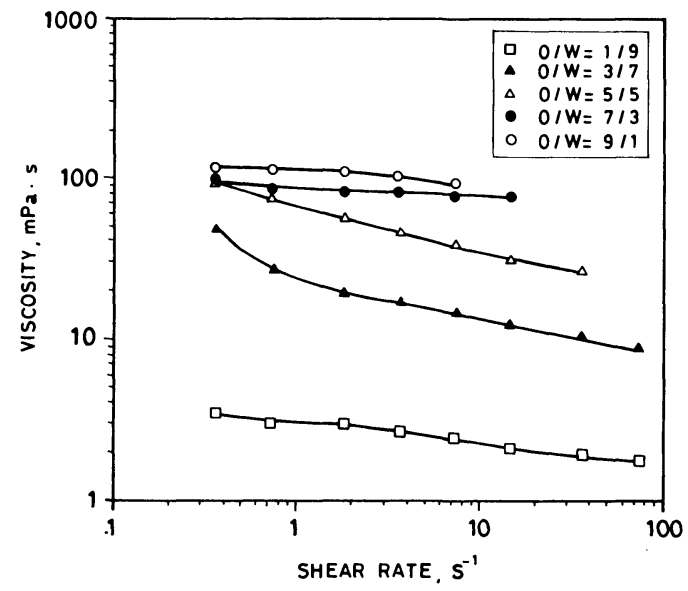

Fig. 2 Rheological Properties of Saudi Heavy Oil Emulsions

Table 3 Values of $H, n$, and $A$ of Heavy Oil Emulsions Using $15 \% \mathrm{NaCl}$ Concentration

\begin{tabular}{ccclc}
\hline Oil/water & $H[\mathrm{mPa} \cdot \mathrm{s}]$ & $n$ & \multicolumn{1}{c}{$A$} & $\rho\left[\mathrm{kg} / \mathrm{m}^{3}\right]$ \\
\hline $9 / 1$ & 87.66 & 0.950 & 143.65 & 885.4 \\
$7 / 3$ & 110.69 & 0.983 & 154.5 & 887.5 \\
$5 / 5$ & 67.89 & 0.704 & 140.0 & 890.7 \\
$3 / 7$ & 27.08 & 0.695 & 118.8 & 895.5 \\
$1 / 9$ & 3.02 & 0.871 & 165.88 & 897.2 \\
\hline
\end{tabular}

indicates that the viscosity decreases with either increase in shear rate or decrease in oil concentration, except that viscosities for the oil/water ratio of $7 / 3$ are higher than those for the ratio of $9 / 1$. This means that the emulsions studied exhibit pseudoplastic behavior under the test conditions. These measurements were correlated with the power-law model, and the resulting values of $H$ and $n$ are given in Table 3.

The flow test results (pressure drop and flow rate), values of $H, n$, and density are given in Table 3, and the properties of the ten sandstone cores given in Table $\mathbf{1}$ were used to calculate the friction factor and Reynolds number from Eqs. (1) and (4). The friction factor and Reynolds number data of each oil/water ratio were correlated with Eq. (6) and the values of the constant " $A$ " are given in Table 3.

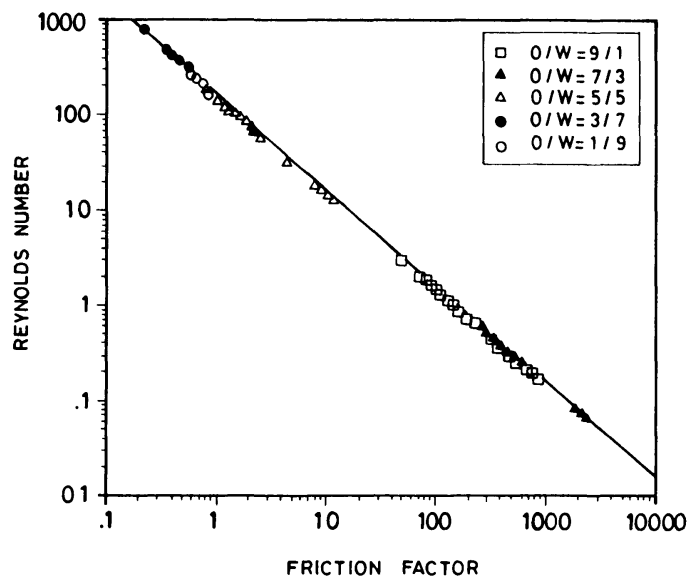

Fig. 3 Friction Factor $v s$. Reynolds Number for Heavy Oil Emulsion

In order to obtain an average correlation for all emulsions studied, the friction factor and Reynolds number of the various emulsions are plotted in Fig. 3. This figure shows that the friction factor decreases with increasing Reynolds number or with decreasing oil concentration. These data were correlated with Eq. (6) and the correlation obtained is

$$
f=\frac{155.34}{R_{\mathrm{epl}}}
$$

Equation (7) can be used to predict the pressure drop resulting from the flow of heavy oil emulsions through sandstone cores. An equation similar to Eq. (7) for Newtonian fluids can be obtained by combining Eqs. (1) and (2) and Darcy's law.

$$
f=\frac{150}{R_{\mathrm{epl}}}
$$

Comparing Eq. (8) with Eq. (7), it can be concluded that the value of the constant " $A$ " in Eq. (7) slightly differs from that of Eq. (8). The difference between the two values of the constant is small and may be related to the acceptance of viscosity data in calculations of friction factor and Reynolds number or the properties of emulsion, or both.

\section{Conclusions}

Based on the experimental results and the calculated values of friction factor and Reynolds number, the following conclusions were obtained. 1) The heavy oil emulsions studied using $15 \%$ 
$\mathrm{NaCl}$ concentration, $2 \% \mathrm{HCl}$, and $0.5 \%$ Triton X-100 exhibited pseudoplastic behavior at $25^{\circ} \mathrm{C}$.

2) An average correlation was developed to describe the flow of heavy oil emulsions through sandstone cores.

3) It was confirmed experimentally that friction factor and Reynolds number obtained from core tests are inversely proportional regardless of emulsion composition or viscosity.

\section{Nomenclatures}

$A \quad$ : constant in Eq. (6)

$D_{\mathrm{p}} \quad$ : effective particle diameter

$f$ : friction factor

$H$ : consistency index

$K$ : permeability resulting from the flow of emulsion through porous media

$K_{\mathrm{i}} \quad$ : initial permeability of the core

$L \quad$ : core length

$n$ : flow behavior index

$P \quad:$ pressure

$R_{\text {epl }}$ : Reynolds number for power-law fluids

$R_{\text {en }}:$ Reynolds number for Newtonian fluids

$V_{\mathrm{o}}$ : superficial velocity $<$ Greeks $>$

$\rho \quad$ : density $\begin{array}{llr}\mu & : \text { Newtonian viscosity } & {[\mathrm{Pa} \cdot \mathrm{s}]} \\ \mu_{\mathrm{eff}} & : \text { viscosity level parameter for power-law fluids } \\ & & \\ \phi & : \text { porosity } & \left.\mathrm{s}^{n} \cdot \mathrm{m}^{1-n}\right] \\ \tau & : \text { shear stress } & \\ \gamma & : \text { shear rate } & {[\mathrm{Pa}]} \\ & {\left[\mathrm{s}^{-1}\right]}\end{array}$

\section{References}

1) Blake, F. C., Trans. AIChE, 14, 415 (1922).

2) Sadowski, T. J., "Non-Newtonian Flow Through Porous Media," Ph. D. Thesis, Chem. Eng. Dept., University of Wisconsin, Madison, 1963.

3) Sadowski, T. J., Bird, B., Ind. Eng. Chem., 61, 118 (1969).

4) Camy, J. P., Marsden, S. S., Hung, J. E., Arihara, N., Casse, F. J., Alvarado, D. A., Mandel, L., Mobarak, S., Gozales, H. O., Mao, M. L., Samaniego, F., Romero, E., Rivera, J., Marius, C. G., Proceedings of the Int. Symp. on Oil Fields Chemistry, SPE, Dallas, Texas, Jan. 16-17, (1975), SPE 5299.

5) Richardson, E. G., J. of Colloid Sci., 8, 367 (1958).

6) Marsden Jr., S. S., Raghavan, R., J. Inst. Pet., 273 (1973).

7) Alvarado, D. A., Marsden, S. S., Soc. Pet. Engr. J., 369 (1979).

8) Govier, G. W., Aziz, K., "The Flow of Complex Mixtures in Pipes," Chapter 5, van Nostrand Reinhold Co., New York (1982).

9) Christopher, R., Middleman, S., Ind. Eng. Chem. Fundam., CI, 422 (1965)

\title{
要 旨
}

\section{多孔啠媒体内における重襄油エマルションの流动}

\author{
Adnan E. Omar, Saad El-Din M. Desouky \\ Petroleum Eng. Dept., King Saud Univ., P. O. Box 800, Riyadh 11421, Saudi Arabia
}

流体のレオロジーと砂岩コアを用いた流動試験のデータか

ら, 砂岩中を水/油エマルションが流動するときの摩擦係数と レイノルズ数の関係を導いた。得られた相関から，多孔質媒体 中を流体が流れるとき，特に界面活性剤を用いた EORにおけ る圧力降下を求めることができる。
実験に用いた原油と砂岩コアはサウジの油層から得られたも のである。実験に用いられたエマルションは, べき乗則に従う 擬塑性流体であった。流動試験の結果, 摩擦係数とレイノルズ 数はエマルションの組成および粘度によらず，反比例すること が確認された。

\section{Keywords}

Emulsion, Porous media, Friction factor, Reynolds number, Pseudoplastic fluid, Viscosity 